\title{
Hierarchy of Arthur's Needs: A Reflection of Psychological and Social Problems in Joker Movie
}

\author{
Indah Wardaty Saud (Corresponding Author) \\ indah.saud@iain-manado.ac.id \\ Institut Agama Islam Negeri Manado, Indonesia \\ Indah Diah Utari Mahajani \\ indahutari@gmail.com \\ Universitas Muhammadiyah Gorontalo, Indonesia
}

\begin{abstract}
The film brings a cultural instrument that educates people. People can see the psychological aspects through the characters and social situation, which influences the characterization in the film. This study examines Joker (2019) a movie containing the psychological conflicts and the society problems of discrimination system in this era which affects much on the character of Arthur who suffers pseudobulbar affect. The researchers used Maslow's Theory of Human Needs to analyze Arthur's need to reflect society's problem needs. A descriptive qualitative method was used in this study because it focused on the human needs of the main character. The primary data was taken from the dialogue in the film, while the secondary data was from articles discussing Arthur Fleck and society as the film's setting. The technique of collecting data was documentation while analyzing data was divided into three stages. First was data reduction; the researcher classified the data of Arthur 's needs and explained why they are classified into those categories. The second was data display; the data is structured and presented so that it is easier to be understood. Then, the researchers presented the data into the display categorized on each dialogue that reflected Arthur's needs levels and the social problems faced by Arthur. Finally, the conclusion was delivered by describing Maslow's data and theory of human needs and elaborating the description of social issues at that era. The result revealed Arthur Fleck had difficulty fulfilling his basic human needs such as physiological, safety, love and belongingness and esteem needs because of the government's broken system and how society treats a person who suffers mental health disorder like Arthur Fleck. The failure to fulfill those needs has made Arthur actualize himself as the coldblooded clown, The Joker. Then, it helps him to be recognized and being acknowledged by others.
\end{abstract}

Keywords: Human needs; psychological and social problems; Maslow; Arthur. 


\section{A. INTRODUCTION}

Joker, directed by Todd Phillips, is one film that delivers a great message to the audience. The dark story of the Joker, the evil clown from Gotham City, succeeds in attracting the world's attention, including Indonesia. Joker has become a trending topic on all social media portals since the release date. Sad, tragic, and deep madness are three things that the audiences can see in almost every part of this movie.

The story of Joker becomes the beginning of chaos in Gotham City. It explains who the Joker is, how Arthur Fleck becomes Joker, and how he presents Batman's eternal enemy in Gotham. If in the previous DC movies, the audiences were always served by Gotham as a city that was destroyed and failed, here the audiences will see how it all started. The Joker is a crazy villain, Bruce Wayne or Batman as a hero of the story is much more lovable, but by releasing this film, Todd Phillips tries to bring us to stand in Joker's perception.

Literary work studies discussed the psychological aspects of Joker had been focused on the types of personality disorders and the causes of Joker's experiences with a personality disorder. As (Rahman, 2020) used Theodore Millon's theory to analyze Arthur Fleck's characterization and showed that Arthur has several personality disorders. Psychological and environmental factors trigger personality disorder in Arthur's character. The five types of personality disorder experienced by Arthur are borderline personality disorder, depressive personality disorder, sadistic personality disorder, antisocial personality disorder, and negativistic personality disorder.

Another was (Permatasari, 2020), who explored the characteristics of Joker by using Altruism and Altruistic Love theory by focusing on Fleck as the main character. His characteristics have dramatically changed through tragically unpleasant experiences he passed on from a kind-hearted person and became a cruel and impulsive man as he has been disappointed by his mother who lied to him, backstabbed by his friend, and got bullied for his mental condition. s. even though he is depicted as a cruel and impulsive person, Arthur still has altruistic sides. His altruistic side appears in terms of sincerity and solidarity aspects. He didn't kill his friend, Gary, and set him free as he thought that Gary never treated him bad, betrayed him, and was always nice to him.

Fitriani (2019) analyzed the main characters in the movie "Joker" by Todd Phillips. This research used the theory of the psychological aspect is based on Sigmund Freud's 
view, such as the Id, ego, and superego. The main character's Id was about his negative thought about the unfair life due to the negative response from his surroundings. It was a pleasure principle that worked through the primary process of thinking. The main character's ego was about killing the wrong people. A reality principle worked to satisfy the Id's demands through secondary process thinking. The main character's superego was keeping good people to be alive. It was a moral principle that reflected an idealistic standard through the rules of parents and society.

Furthermore, Baharuddin \& Gosal (2021) elaborated on the forms of exploitation social discrimination in Joker's film and the impacts of the exploitation and social discrimination in the film. This study used one of the branches of Marxism's sociological theory, class contradiction analysis, and the theory of communication science called critical discourse analysis to analyze the issue of news media coverage in this film. The results of this study indicate that the form of exploitation and social discrimination in the Joker film is divided into three areas, namely (1) the Health Sector, (2) the Labor Sector, and (3) the Media News Sector.

Similarly, this present study described psychology using the Hierarchy of Human Needs theory of Maslow. Maslow was very interested in human potential. He believed that the only type inspected was a very healthy person for checking psychological condition. He was critical to Freud and other psychological experts' theories of behaviorism, who only understood the natural behavior by only inspecting neurotics and other people with many or great problems. Maslow summarized that every human being was born with automatic needs. Universal needs push us to grow up and for selfactualization. Studies on human needs in literary works vary from one another. The first was the Hierarchy of Human Needs through The Main Character in Hitch Film (Andini, 2017). This study observed the main character in Hitch movie by analyzing his characteristics and defining them through Abraham Maslow's Theory of the Hierarchy of Human Needs. The result shows that Hitch, as the main character, can fulfill all of the five levels of needs Physiological Needs, Safety Needs, Love Needs, Esteem Needs, and Self- Actualization Needs. An opposite result showed by (Haifa, 2015) in "A Main Character Analysis Of "Ralph" In Wreck- It Ralph Film Using Hierarchy Of Human Needs By Abraham H. Maslow”. It revealed that the main character is unconfident and decided to change his life to be like another man. He thought that being a hero or a 
winner could make his life perfect. He just wanted to be like Felix, his partner in his work, who always got a prize and loved the people. Just because he does not feel confident in himself, who works as a wrecker, or his people say he is a bad guy, he has to face a long journey to find what he needs in his life. He tried to pursue his esteem needs and actualize himself to make his perfection of life. In the middle of his pursuit, he realized that being another man was bad because he had lost everything he already had before. Finally, he felt that being truly him is better. He decided to serve forever in his job, peaked his needs, and actualized his life in his career.

Maslow constructed the human needs by five rungs: physiological need, safety need, love and belongingness need, esteem need, self-actualization need. Psychological, security, social, and self-esteem are deficiency needs that arise due to deprivation. Satisfying these lower-level needs is important to avoid unpleasant feelings or consequences. Maslow termed the highest pyramid level as growth needs, also known as needs B-needs. Growth needs do not stem from a lack of something but rather from a desire to grow as a person (Cherry in Haifa, 2015). Physiological Needs are usually taken as the starting point for motivation theory are the so-called physiological drives. Two recent lines of research make it necessary to revise our customary notions about these needs: first, the development of the concept of homeostasis, and second, the finding that appetites (preferential choices among foods) are a fairly efficient indication of actual needs or lacks in the body. Homeostasis refers to the body's automatic efforts to maintain a constant, normal bloodstream state. Additional, physiological needs consist of oxygen, food, water, and this list could extend to include other hormones, vitamins, etc. A person who lacks food, safety, love, and esteem would most probably hunger for food more strongly than for anything else (Andini, 2017).

If the physiological needs are relatively well gratified, there then emerges a new set of requirements, which we may categorize roughly as the safety needs (security; stability; dependency; protection; freedom from fear, anxiety, and chaos; the need for structure, order, limits; strength in the protector; and so on). They may serve as the almost exclusive organizers of behavior, recruiting all the capacities of the organism in their service, and we may then fairly describe the whole organism as a safety-seeking mechanism (Andini, 2017). 
Suppose both the physiological and the safety needs are fairly well gratified. In that case, there will emerge the love and affection and belongingness needs, and the whole cycle already described will repeat itself with this new center. As never before, we will feel keen, the absence of friends, or a sweetheart, or a wife, or children. We will hunger for affectionate relations with people in general, namely, for a place in our group or family, and we will strive with great intensity to achieve this goal. We will want to attain such a place more than anything else in the world and may even forget that once we were hungry, we sneered at love as unreal, unnecessary, or unimportant. We will sharply feel loneliness, ostracism, rejection, friendlessness, or rootlessness. The fact that the love needs involve both giving and receiving love (Andini, 2017).

As human beings, we needor desire a stable, firmly based, usually high evaluation of ourselves for self-respect, or self-esteem, and the esteem of others. These needs may therefore be classified into two subsidiary sets. First, these are the desire for strength, achievement, adequacy, mastery and competence, confidence in the face of the world, and independence and freedom. Second, we have what we maycall the desire for reputation or prestige (defining it as respect or esteem from other people), status, fame and glory, dominance, recognition, attention, importance, dignity, or appreciation. Satisfaction of the self-esteem need leads to self-confidence, worth, strength, capability, and adequacy of being useful and necessary in the world (Andini, 2017).

Finally, Maslow emphasizes that psychological growth is carried out through selfactualization work. Self-actualization implies the duration, constant involvement in the work of growth, and the development of abilities to the maximum possible, not satisfied with less laziness or lack of self-confidence. A teacher should teach, a songwriter writes lyrics, and an artist must perform if he is ultimately at peace with himself. Whata man can be, he must be. He must be true to his own nature. This need we may call selfactualization (Andini, 2017). However, the process of self-actualization may be limited: the negative influence of experience and the resulting habits that close us to unproductive behavior; social influences and group pressure, which often acts against our tastes and judgments; internal defenses that tear us away from ourselves (Nikadambaeva, 2021). 


\section{B. RESEARCH METHOD}

This study uses qualitative research methodology to analyze human needs as psychological phenomena by elaborating on social aspects in the film. The technique of collecting data was documentation while analyzing data was divided into three stages. First was data reduction; the researcher classified the data of Arthur 's needs and explained why they are classified into those categories. The second was data display; the data is structured and presented so that it is easier to be understood. Then, the researchers presented the data into the display categorized on each dialogue that reflected the Arthur's needs levels and the society problems faced by Arthur. Finally, the conclusion was delivered by describing the data and theory of human needs by Maslow and elaborating on the description of social issues at that era.

\section{FINDINGS AND DISCUSSION}

\section{Findings}

\section{Physiological Need}

The researchers show some of the four needs stages before reaching selfactualization, the physiological needs. According to Maslow (Trivedi, 2019) and (in Kaur, 2013), physiological needs are usually the starting point for fulfilling human needs. Thus, physiological needs are the basic needs for oxygen, food, water, and relatively constant body temperature. Physiological needs are the strongest needs because if a person is deprived of all needs, the physiological needs will come first in the person's search for satisfaction.

Arthur Fleck is a grown man who still lives with his mother in an apartment in the corner of Gotham City. Todd Phillips as the director of this movie never showed how hard Arthur Fleck fulfills his needs of oxygen, food, water, etc. He has food to eat, water to drink, no problem breathing, and a place to sleep. However, the physiological needs and how to satisfy them vary in every person. As a person with a mental disorder, Arthur's physiological conditions covered the need to consume some medicines.

\section{Datum 1}

Arthur Fleck : I was wondering if you could ask the doctor to increase my medication.

Social Worker : Arthur, you are on seven different of medications. Surely, they must be doing something.

Arthur Fleck : I just don't want to feel so bad anymore.

(In minutes 00:07:19 - 00:07:3) 
The conversation above in datum 1 happened when Arthur met a social worker (50's), African American. This 40-years-old man who works as a clown for a living has a free consultation schedule he regularly does for an examination for his mental health condition. It shows that he has a history of mental illness. He has a prior hospital stay in history; he is on seven different medications and has some mood dysregulation.

\section{Datum 2}

Social Worker : Arthur, I have some bad news for you. They've cut our funding. We're closing down our offices next week. The city's cut funding across the board. Social services are part of that. This is the last time we'll be meeting.

(In minutes 00:40:19 - 00:41:35)

\section{Datum 3}

\section{Arthur Fleck : How am I supposed to get my medication now? Who do I talk to? \\ Social Worker : I'm sorry, Arthur. \\ (In minutes 00:42:02 - 00:42:13)}

After the sad news that he could not increase his medication, in datum 2 and 3 reflected the other scene, Arthur made another appointment with the social worker. Arthur sits in front of that woman and shares his daily life story with a cigarette in his right hand, but she arrogantly cut his words with other sad news. Gotham City will stop funding for the program, so the social worker will not be available to continue Arthur's therapy.

The audiences can see from the beginning of the movie that Arthur Fleck suffers from a mental health disorder, and he needs medicine to help him lessen or even prevent him from being stressed out of his illness. Still, no one seems to want to allow him to satisfy his needs. In other words, Arthur's physiological needs were not fulfilled.

\section{Safety Need}

The second level is the need for safety, such as needs; security, stability, protection, freedom, fear, chaos, neat or well organized, strong in defense, and so on. Maslow also shows many indications that lack of safety is found in adults. The indication exhibit behaviors that tend to seek protection to stronger people or systems, or to people who can provide a sense of security. This behavior is very similar to children who are afraid and react to a dangerous situation. 
Datum 4

Street Gang : Hey! Hey you guys! Let's go! We got the board!

Arthur Fleck : Stop them! Make them stop! Stop, that's not your board! Give it back!

Street Gang : Hey clown head! Come on! He is weak! Beat him up, come on! He can do nothing!

(In minutes 00:40:19 - 00:41:35)

Datum 4 shows how a man like Arthur is treated in society. He is an adult but gets bullied easily by a group of teenagers, causing him to chase them into an alley where they broke the sign on him and beat him violently. It is brutal and vicious, but a clown barreling down the street has got to be a joke. Everyone is watching, but nobody on the street stops to help.

\section{Datum 5}

$\begin{array}{ll}\text { Arthur Fleck } & : \text { (laughing) } \\ \text { Wall Street Guy } & \text { : What's so fucking funny, asshole? } \\ \text { Arthur Fleck } & \text { : No, please don't! } \\ \text { Wall Street Guy } & \text { : Hold him! Hold Him! } \\ \text { Arthur Fleck } & \text { : Hey, stop! } \\ \text { Wall Street Guy } & : \text { You like kicking, huh? Hold him tight. } \\ \text { (In minutes 00:31:57 - 00:32:18) }\end{array}$

In another scene, in datum 5, Arthur gets on the subway home after getting fired for bringing a gun to work. He gets on the subway home. In the subway, he watched how three young wealthy Wall Street stockbrokers harassed a young woman from Wayne Enterprises as one of them was asking her if she wanted French fries. Seeking to save her, Arthur bursts out in his uncontrollable laughter. He gets the attention of the brokers as the woman moves to a different cart. They ask Arthur why he was laughing. Arthur tries to show his license out of his bag, but instead, one of them takes his load away from him, and then they start to attack Arthur as he tries to fight back. Then one grabs him from behind, and the other hit him to the ground. As Arthur is on the ground, all three start kicking him. Based on these interpretations, it concluded that Arthur's safety needs were not fulfilled as well.

\section{Love and Belongingness Need}

\section{Datum 6}

Sophie Dumond : Were you following me today?

Arthur Fleck : Yeah.

Sophie Dumond : I thought that was you, I was hoping you'd come in and rob the place.

Arthur Fleck : I have a gun. I could come by tomorrow.

Sophie Dumond : You are so funny, Arthur. 
Arthur Fleck : You know, I do a stand-up comedy. You should maybe come see a show sometime.

Sophie Dumond : I could do that.

Arthur Fleck : Yeah?

SophieDumond : You will let me know when?

Arthur Fleck : Yeah.

(In minutes 00:27:10 - 00:27:57)

The datum six above shows how happy Arthur is when he is with Sophia. Sophia's companion has made Arthur more affectionate to her. He feels alive. He feels loved. Despite his failure and attempts to take care of his mother in their shared small rotten apartment in Gotham, he developed an obsession with a cynical young woman named Shopie Dumond, a banker and single mother, after he met her in an elevator. One of this movie's big twists occurs when Arthur "dates" Sophie only to find out that those flirty conversations were completely in his imagination.

\title{
Datum 7
}

\author{
Thomas Wayne : Can I help you, pal? \\ Arthur Fleck : What? Yeah. No I, I- \\ Thomas Wayne : You need to get in here or something? \\ Arthur \\ : Dad. It's me. \\ Thomas Wayne : Excuse me? \\ Arthur Fleck : My name is Arthur. I'm Penny's son. I, I know \\ everything. And I don't want anything from you. Well... maybe a hug. \\ Thomas Wayne : Look pal, I'm not your father. What's wrong with \\ you? \\ (In minutes 01:05:24 - 01:05:50)
}

The conversation above happens when Arthur comes to Wayne Hall to meet Thomas Wayne and confront him all the facts he had just found out. It's all very emotional for him, but Thomas looks at him like crazy. As someone who grew up fatherless, all he wants is a little bit of warmth or a hug, he never meant to make anyone feel uncomfortable. Still, instead of makes a reunion scene between a father and a son, Thomas Wayne rudely tells him that Arthur is not his son. He tells Arthur that he was adopted. When Arthur was four years old, Penny was arrested and committed to Arkham State Hospital. Not only that, but Thomas Wayne also punched him on the face as a good-bye sign. Arthur has no idea why everyone is so rude to him, but it seems like this cruel world forces him to take all of that.

\section{Esteem Need}

The fourth level that came up after the third is esteem need. Like other human beings, Arthur Fleck, as the main character, also has the desire for a stable and firmly 
based, and it is usually high evaluation of him for self-respect or self-esteem and the esteem of others. If it is not fulfilled, the main character feels inferiority, weakness, and helplessness.

\title{
Datum 8
}

\author{
Woman on bus : Can you please stop bothering my kids? \\ Arthur Fleck : I wasn't bothering him, I was... \\ Woman on bus : Just stop.
}

Arthur suddenly starts to laugh. He covers his mouth trying to hide it. He shakes his head, laughter pausing for a moment, but then it comes on stronger. His eyes are sad. It actually looks like the laughter causes him pain.

Woman on bus : You think it's funny?

Arthur shakes his head no, but he can't stop laughing. He reaches in his pocket and pulls out a small card. He hands it to the woman. The card itself reads: "Forgive my laughter. I have a condition (more on back)". She turns the card over and there is a bunch of information in small writing, "It's a medical condition causing sudden, frequent, uncontrollable laughter that doesn't match how you feel. It can happen in people with a brain injury or certain neurological conditions." She doesn't read it. She just shakes her head annoyed and throws the card on the ground.
Arthur Fleck
: I'm sorry.
(In minutes 01:12:07 - 01:13:04)

The conversation above happened when Arthur was sitting in the back of a crowded bus, looking out the window at the city passing him by. He feels somebody staring turns to see a sad-eyed three-year-old boy, face puffy from crying, sitting on his knees looking at him. His mother's facing forward, but you can tell she is angry even from behind. Arthur does not know where to look, feeling conscious and small. He gets back into character, smiling like a clown and, covers his face with his hands, starts playing the peek-a-boo game with him. The boy stares back at him for a moment then giggles, but unfortunately, this boy's mom hates it and starts to scold Arthur

\section{Datum 9}

Arthur Fleck : You don't listen, do you? I don't think you ever really hear me. You just ask the same questions every week. "How's your job?" "Are you having any negative thoughts?" All I have are negative thoughts. But you don't listen anyway. I said, "For my whole life I didn't know if I even really existed." But I do. And people are starting to notice. (In minutes 00:40:45 - 00:41:21)

It's important to understand that mental illnesses are real illnesses. Mental illnesses are health problems that affect how we think about ourselves, relate to others, and interact with the world around us. They affect our thoughts, feelings, abilities, and 
behaviors. Suffer from mental illness is never easy for Arthur Fleck. It is hard for him to express his feelings to other people, and to get free social services helped him enough to survive. He finally has someone to talk to; he expects to share everything he feels with the social worker. No one wants to listen to him, even the social worker. All Arthur Fleck needs are to be heard and understood, but by seeing the data above, it seems like it is too much to ask.

\section{Self-Actualization Needs}

The ultimately called self-actualization, the tendency for people to become actualized in what they are. This tendency may be phrased as the desire to become everything that people are capable. The clear appearance usually rests upon some prior satisfaction of the physiological, safety, love and belongingness, and esteem needs.

\section{Datum 10}

Arthur Fleck : Hey, Penny. Penny Fleck. I always hate that name. You used to tell me that my laugh is a condition, that there is nothing wrong with me. You are right, that is me. Happy. I haven't been happy for one minute of my entire fucking life. But you know what's funny? You know what really makes me laugh? I used to think my life was nothing but a tragedy, but now, now I realize it's all just a fucking comedy.

(In minutes 01:20:02 - 01:21:18)

Arthur already considers his life a disaster, and he is seeking a zone where he always tried to find he is not waste. Still, each attempt makes it contradictory and more intense about negative thoughts, as he mentioned when he talked to the social worker, "All I have are negative thoughts." Penny had been asking him to be happy but without doing anything right for him. When he found that his mom also betrayed him by hiding the truth from the beginning, he thought she was useless and had no right to live. After finishing his hurtful speech, Arthur kills his mother, suffocating her with a pillow, then fully descends into madness, no longer tethered to any friends or family.

\section{Datum 11}

Joker : Have you seen what it's like out there, Murray? Do you ever actually leave this studio? Everybody just yells and screams at each other. Nobody's civil anymore. Nobody thinks what it's like to be the other guy. You think men like Thomas Wayne ever think what it's like to be a guy like me? To be anybody but themselves. They don't. They think we'll all just sit there and take it like good little boys. That we won't go wild. 
Murray Franklin : You finish? So much self-pity, Arthur. You sound like you're making excuses for killing three young men. Not everybody's awful.

Joker

: You're awful, Murray. There is no more laughter. The audience is watching this exchange with full attention.

Murray Franklin : Me? How am I awful?

Joker : Playing my video, inviting me on the show,-- You just wanted to make fun of me. You're just like the rest of them, Murray. Everything comes too easy for you.

Murray Franklin : (on the spot; defensive) You don't know the first thing about me, pal. Look what happened because of what you did, what it led to. There are riots out there. Two policemen are in critical condition, someone was killed today.

Joker : How about another joke, Murray?

Murray Franklin : No, I think we've had enough of your jokes

Joker : What do you get when you cross a mentally-ill loner with a system that abandons him and treats him like trash? (pulling the gun) I'll tell you what you get. You get what you fucking deserve... (In minutes 01:43:34 - 01:45:13)

Arthur shows up at Murray Franklin's show dressed in his Joker best and asks Murray to refer to him with that soon-to-be-infamous moniker. While the show is on air, Joker admits to killing the Wall Street guys and blasts the world for not caring about people like him. He then pulls out his gun and shoots Murray as payback for embarrassing him on air.

\section{Discussion}

Arthur Fleck is a grown man who still lives with his mother never showed any difficulties in fulfilling the needs of oxygen, food, water, etc. He has food to eat, water to drink, no problem breathing, and a place to sleep. However, as a person with a mental disorder, Arthur's physiological needs covered the need to consume some medicines. It follows the statement that additionally, physiological conditions consist of needs for oxygen, food, water, and this list could extend to include other hormones, vitamins, etc. (Maslow in (Andini, 2017). It means that consuming some vitamins and medicines was regarded as the physiological need for certain people and it is what Arthur needed in his life. When there was an obstacle to obtaining the medication, Arthur was distracted by his sleepless nights. He had to consume the medicines to help him feel relaxed. In datum 1, "I was wondering if you could ask the doctor to increase my medication." The data shows us how Arthur begged the social worker to increase his medication so he could feel better. As (Agisa et al., 2021) argued, Arthur suffered from Neuroticism, a 
personality that experiences negative emotions such as fear, anxiety, irritability, depression, and an uncomfortable feeling that impacts the inability to adapt. For some people, medications are a short-term solution to get them over an immediate crisis. It helps some people lead the kind of lives they want to lead, without relapses and readmissions to hospital, but the social worker refuses to give him what he really needs on this scene. Further, the government also decided to stop distributing medicines for Arthur's therapy. It could be seen that there are discriminative phenomena where the health insurance that should have been given to the people is finally cut off unilaterally by the government. It shows that the government does not bring welfare and equality. This eventually causes Arthur's mental sickness is getting worse. To link this with the problem of society in that era, it was evident that the government made the most devastating change that drastically altered American society: the closing of the hospitals for the mentally ill. The rapid closure of the fare cut and the closure of the asylums left thousands of mentally unstable patients on the streets, dramatically increasing unemployment and homelessness (Anisha, 2021). Thus, the society, in this case, the government, affected the failure of Arthur in fulfilling the physiological need, and it leads Arthur to feel difficult to achieve the next level of human needs.

Ironically, Arthur did not obtain the Safety need as well. As a poor citizen having a certain health condition and living with his delusional mother, Arthur always faced bullying by people surrounding him. He is an adult but gets bullied easily by a group of teenagers, causing him to chase them into an alley where they broke the sign on him and beat him violently. It is brutal and vicious, but a clown barreling down the street has got to be a joke. Everyone is watching, but nobody on the street stops to help. This is in line with the result of another study that proved that the street children stole his board sign in the beginning of the story, hardly hit his face with the board and beat him up until he became physically weak (Permatasari).

Furthermore, (William \& Winduwati, 2021) described verbal abuses experienced by Arthur were no respect and unfair treatment of lower-class society. This explained that jobs in the informal sector (like comedians) do not get legal protection from the government. The government only appreciates and protects human rights to those in the elite class and work in the formal sector. Thereby, it indicates the social discrimination of the two classes between those who work as government elites in routine jobs and 
those who only work in informal jobs. For instance, the insecurity of casual workers also happened in Thailand. Million informal workers had injuries or accidents from work in 2012. It was about ten times higher than that experienced by formal workers. Most of them had sharp cuts or wounds, falls, being hit by an object, burns, vehicle accidents, exposure to harmful chemicals, and electric shock (Kongtip et al., 2015). It concluded that insecurity of informal workers truly occurred in society, and the government was responsible for minimizing the criminal and bullying in informal sectors. Thus, as a representative of informal worker from lower class society who was a clown, Arthur did not get the safety needs for himself.

Love and belongingness were tried to get by Arthur through the imagination of having a conversation and lovely moment with Sophia, the career woman who lived in the same department. Additionally, he was struggling to find his father's love, which was told by his delusive mom, Penny. Loves that were wanted in his life were not real. They were all only the result of imagination. This was in line with the impact of the study that Arthur was characterized as a person who wanted to be admitted because he always felt lonely (Yuliana \& AM, 2019). In other words, Arthur did not fulfill the need for love and belongingness. Feeling that no one truly loved and cared about him affected his personality became depressive; as stated by (Rahman, 2020), the personality disorder performed by Arthur was depressive. He reacts like a sad, discouraged, pessimistic, and brooding.

Similarly, (Permatasari, 2020), in her study, revealed the depression of Arthur "that the medical records showed that his mother had been committed to the insane asylum. The files stated that she often had delusions about Thomas's secret love, and there were adoption records for an unnamed baby. After successfully finding out what happened to his past life, Arthur was so depressed and disappointed". To relate this with the social phenomena, the lower class people had no right to get close and relationship with upperclass people. In the film, Penny reflected it as a lower-class woman who admired much on Wyne from an upper close man. She asked for help because Wyne would help them for a better life because she has worked for that family for years (Marwati, et.el, 2021). It reflected how oppression people were depended on superiors.

Moreover, in performing self-esteem needs, Arthur was also failed, and the effect of this was the character feeling inferiority, weakness, and helplessness. This film 
illustrated the criminal behavior that can be carried out by someone who is physically and mentally stronger than the victim. Arthur was tortured until he was helpless (Rosita $\&$ Prathisara, 2021). The suffering mental disorder was not easy for Arthur to carry out problems in his life. He did not have a good self-image as a human. As a result, Arthur had a borderline personality disorder, an illness marked by an ongoing pattern of varying moods, unstable self-image, and behavior. The symptoms often result in impulsive actions and relationship problems (Rahman, 2020). As a result of all the failure to fulfill four basic human needs, Arthur extremely actualized his personality to be different, from the weak person to a strong one. A kind-hearted person changed into a sadistic one. In society reflection, as stated by (Agung et. el, 2020), Joker represents the dark side of humans and even the hidden desires of humans that have been alienated from normality dominated by certain power classes. The Joker characters then became symbols of class resistance that emerged from a life controlled by the construction norms of the power class society. He felt satisfied by dominating, intimidating, and humiliating others. He killed Penny because of the lies for his whole life. His unkind friends betrayed him and shot Murray live on TV because he embarrassed Arthur at the previous show. These changes were regarded as negative self-actualization processes portrayed by Arthur because he was not successful in fulfilling the physiological, safety, love, and self-esteem needs. He had been through much negative experiences in live. This was as a symbol of the struggle of lower people in getting respect and position from upper class people.

\section{CONCLUSION}

The conclusion of the entire analysis in this study is the researcher has found that Arthur Fleck had difficulty in fulfilling his basic human needs such as physiological, safety, love and belongingness, and esteem needs because of the broken system of the government and how the society treats a person who suffers mental health disorder like Arthur Fleck. The unfulfilled of those basic human needs made Arthur actualize himself as the cold-blooded clown; The Joker. It helps him to be recognized; being acknowledged by others. This study limited on the discussion on the analysis of Arthur's needs and social problems in that era; thus, it is suggested to further researchers to explore more about linguistics aspect inside the Joker Film 


\section{REFERENCES}

Agisa, M. A., Lubis, F. O., \& Poerana, A. F. (2021). Analisis semiotika Roland Barthes mengenai pseudobulbar affect dalam film Joker. ProTVF, 5(1), 39. https://doi.org/10.24198/ptvf.v5i1.29064

Andini, M. (2017). Hierarchy of human needs through the main character In Hitch film. Syarif Hidayatullah State Islamic University.

Anisha, A. A. (2021). Boundary between reality and fiction: Analysing socio-political influences of a criminal mind in the film, Joker (2019) (Issue September). BRAC Universit.

Baharuddin, A. F., \& Gosal, A. N. (2021). Exploitation and social discrimination portrayed in the "Joker " movie ( 2019 ): A study of class analysis. 14(2), 217228.

Fitriani, Y. (2019). Analysis of psychological aspects of the main character in movie "Joker" based on Sigmund Freud theory. Humanitatis, 6(1), 109-118.

Haifa, N. (2015). A main character analysis of "Ralph ” in Wreck- It Ralph film using hierarchy of human needs By Abraham H. Maslow.

Kaur, A. (2013). Maslow's Need Hierarchy Theory: Maslow's need hierarchy theory: Applications and criticisms, 3(10), 1061-1064. http://www.ripublication.com/gjmbs_spl/gjmbsv3n10_03.pdf

Kongtip, P., Nankongnab, N., Chaikittiporn, C., Laohaudomchok, W., Woskie, S., \& Slatin, C. (2015). Informal workers in Thailand: Occupational health and social security disparities. New Solutions, 25(2), 189-211. https://doi.org/10.1177/1048291115586036

Lingga Agung, Moh. Isa Pramana K, P. A. (2020). Menelusuri estetika dalam karakterkarakter Joker menelusuri estetika dalam karakter-karakter Joker. Jurnal Rupa, $5(1)$.

Marwati,Sopa, Nurholis, A. H. (2021). Conflicts of social class in movies. CALL, 3(2), 204219.http://www.ejurnal.its.ac.id/index.php/sains_seni/article/view/10544\%0Ah ttps://scholar.google.com/scholar?hl=en\&as_sdt=0\%2C5\&q=tawuran+antar+pelaja $\mathrm{r} \& \mathrm{btnG}=\% 0$ Ahttps://doi.org/10.1016/j.jfca.2019.103237

Nikadambaeva Kholola, Klicheva Karomat, K. G. (2021). The concept of self actualization in the 21st century. Psychology and Education Journal, 58(2), 304308. https://doi.org/10.17762/pae.v58i2.1760

Permatasari, S. D. R. (2020). The altruistic side of Arthur Fleck as the main character in Todd Phillips' Joker (2019). Jhss (Journal of Humanities and Social Studies), 4(1), 36-40. https://doi.org/10.33751/jhss.v4i1.1906

Rahman, A. (2020). Personality disorder as seen in the joker movie by Todd Phillip. The State Islamic University Sultan Thaha Saifuddin Jambi.

Rosita, E., \& Prathisara, G. (2021). Representation of violence value in Joker film. Commicast, 3(1), 92-104. https://doi.org/10.12928/commicast.v3i1.3409

Trivedi, A. J. and A. M. (2019). Maslow's Hierarchy of Needs - Theory of Human Motivation. 7(38), 38-41. http://kalyan-city.blogspot.com/2010/06/maslowhierarchy-of-needs-theory-of.html

William, W., \& Winduwati, S. (2021). Representasi kekerasan non fisik pada film joker (analisis semiotika Ferdinand de Saussure). Koneksi, 5(1), 127. 
https://doi.org/10.24912/kn.v5i1.10195

Yuliana, R., \& AM, S. (2019). The portrayal of the arthur's characterization, impicit meaning, and moral value found in joker movie (2019). Journal of English Education and Entrepreneurship, 8(5), 55. 